\title{
A QUALITIATIVE RESEARCH APPROACH ADOPTED IN AN EGYPTIAN MANAGEMENT CONTROL STUDY
}

\section{Mona Ganna ${ }^{1}$}

\begin{abstract}
This paper shows the details of how I adopted a qualitative research methodology to study the role of management control practices in global production networks (GPNs). The case study is of an Egyptian garment factory that acts as a supplier for a French retailer of sports clothes. The methodology adopted enabled me to trace the supplier-customer relationship, the customer's requirements in terms of the product specification, quality and time of delivery, and the development of the factory along the production network as well as improving the visibility of the factory's operations to achieve instant and continuous control. The paper highlights my reflections on the experience through which I realised an intellectual value of doing a case study.
\end{abstract}

Key Words; Case study; qualitative research; Management Controls; Egypt; global production networks

\section{Introduction}

In his seminal work, Anthony (1965,p 17) defined management controls as "the process by which managers assure that resources are obtained and used effectively and efficiently in the accomplishment of the organization's objectives". Accordingly, management control is located between strategic planning and operational control. The attainment of resources, as well as their effective and efficient use, are assured through the aid of the information provided by the set of management control practices which help the management to guide the behaviour of managers and employees (Horngren et al., 2003). Tools such as budgeting, performance measurements, incentive systems, organizational structure and other administrative activities are among the formal tools of management controls. Anthony's (1965) definition of management control has been the foundation for researchers who adopt the technical-managerial perspective. Management accounting and control practices, from that perspective, are technical activities and are not expected to have roles in the construction of either the organizational life or the social, economic and political life within which the organization functions (Cooper and Hopper, 2006).

However, this line of research has been criticized. Hopwood's editorial paper in the AOS in 1976 claimed that the narrow view of this line of research ignores the role of accounting in national development and presents it merely as an objective set of calculations that have nothing to do with the surrounding organizational and social settings (Hopwood, 1976). Since then, accounting researchers have used theories of social science and psychology in

${ }^{1}$ Department of Accounting, Tanta University,Egypt Email: mona.gana@commerce.tanta.edu.eg 
order to provide a better understanding of the role played by accounting and management control practices (for example Burchell et al., 1980; Tinker, 1980; Cooper, 1983; Hopwood, 1983; Berry et al., 1985; Miller and O'Leary, 1987; Ansari and Bell, 1991). Consequently, the tools of management control have been expanded so that they not only include the formal tools previously mentioned but also reflect informal tools. These tools include professional and cultural controls such as laws, norms, ethics, etiquette and customs, which define behaviour (Tsamenyi et al., 2008).

As a consequence of the time pressure on organizations to provide new products with distinct features of high quality and at reasonable prices, conventional purchasing and selling contractual relationships have been transformed into collaborative relationships that necessitate the maintenance of long-term relationships between suppliers and customers (Bhimani and Bromwich, 2009). Supply chains, strategic outsourcing, joint ventures and network or virtual organizations have become popular organizational forms in the era of globalization (Wickramasinghe and Alawattage, 2007). These boundary-less organizational forms have steered the initiation of more appropriate forms of control that can enable effective management of these distant institutions and guarantee the homogeneity of goals between them. In pursuit of this endeavour, researchers have started to investigate management control systems in inter-organizational relationships (For example Geringer and Hebert, 1989; Groot and Merchant, 2000; Dekker, 2004). These new organizational forms required new types of management accounting and control practices that are able to cope with the challenges of controlling operations in different contexts with significant geographical separation and time differences, as well as bridging the cultural differences between these countries (Groot and Merchant, 2000).

The sustainability of these networks of corporations is materialized through information. Information has become a commodity that helps to enhance the flexibility of decision-making and control (Bhimani and Bromwich, 2009). Along with the advancement in information and communication technologies, the power of knowledge has been shifted from human beings to digitalized information systems. Information systems such as Enterprise Resource Planning systems are used to control the internationally interrelated organizations. New management accounting information systems have become powerful and contingent on the success and survival of multinational corporations.

These structural and informational changes have influenced accounting - and especially management accounting - in several ways. First, they have increased the emphasis on the importance of integrating the stages of planning, decision-making and action, prioritising the integration of strategic decisions with technical and control issues to create the so-called Strategic Management Accounting (SMA: (Bhimani and Bromwich, 2009). Globalization extends the scope of organizations' strategies, and consequently the scope of the information provided by SMA, to include information about global customers and competitors rather than just local ones, and focuses on the industry supply chain rather than the internal value chain within the company (Bhimani and Bromwich, 2009). Accordingly, globalization has added new variables that affect the design of the planning and controlling systems, such as the market location and its effect on customer preferences, and also the complexity of resources and information sources, competitor analysis tasks, resource 
allocation issues and finally the expected fragmentation of these global firms (Dent, 1996). Secondly, evaluation of the cost efficiency of collaborative relationships is more challenging to cost accountants than transactional relationships. The uncertainty of quantity, price and timing of supply in collaborative relationships problematizes the role of cost accountants in conducting the cost or benefit payoff for these contracts (Bhimani and Bromwich, 2009). Another important change in management control systems as a consequence of globalization is the shift from process control to outcome control (Bhimani and Bromwich, 2009).

Researchers have started to question how management accounting and control systems will facilitate or hinder coordination and collaboration between these distant entities located in heterogeneous economic, political and cultural contexts. What kind of role is expected from management accounting systems in sustaining these relationships? The answers to these questions are diverse. The work of Latour and other colleagues on Actor-Network Theory (ANT) has inspired many of the studies in this area (Quattrone and Hopper, 2005; Moilanen, 2007; Boedker and Chua, 2013). In one organizational setting, management control systems were found to be tools for collapsing the distance between headquarters and subsidiaries through providing real-time information (Quattrone and Hopper, 2005). However, in another subsidiary, the same system was used to reproduce the existing structures and was not allowed to lead to radical change in the organization (Quattrone and Hopper, 2005). Interestingly, globalization is diffused not only through the informative power of accounting but also through its ability to transfer the effect and passion of the corporate executives in organisations' headquarters to employees located in the 'local' subsidiaries (Boedker and Chua, 2013). So, management accounting and control practices, from an ANT perspective, are playing the role of a mediator for the transfer of knowledge among networks of relationships (Baxter and Chua, 2003). Such networks can be either global or local.

Although some ANT researchers have conducted their research in multinational organizations, their rejection of the dualistic dichotomy between global and local did not qualify ANT to understand the influence of global forces that happen due to power asymmetry. Other researchers (Barrett et al., 2005; Cruz et al., 2011) have used the work of Giddens (1990, 1991) and Robertson (1992) in order to understand the dilemma of re-embedding or localizing globalization in local contexts. In their work, globalization was perceived as "a uniform pattern of economic, political and cultural organization ... globalization is a powerful force that leads to increasingly homogenized practices" (Cruz et al., 2011). Accordingly, the parent company or the headquarters diffuse a standardized set of management control practices in order to facilitate the visualization of the local subsidiaries (Cruz et al., 2011) and to manage managerial tensions, such as vertical versus lateral relations, convergence versus differentiation, and centralization versus decentralization, which inform the nature of global companies (Busco et al., 2008).

Industrial economics, economic development and geography literature in inter-organizational relationships started early in the 1990s. These approaches did not resonate with management accounting research (see Neu et al., 2014 for an exception). However, these approaches do allow for a broader and deeper understanding of the inter-organizational relationship in the global political, economic, cultural and social context in which it operates. The literature on 
global production networks (GPNs) in economic development and geography has discussed several points and tried to answer three main questions: how are GPNs constructed? How are they governed? What are the consequences of the spread of GPNs? In other words, who is winning and who is losing from the incorporation and/or exclusion from GPNs (Hess and Yeung, 2006)? The issue of control can be directly linked to the second area of the literature: governance (Dekker, 2004).

Drawing from GPN literature, this research is inspired by the case study of an Egyptian garment factory that directs its production for exportation purposes. EGF (the fictitious name chosen for the case factory) operates as a supplier for a French sportswear retailer. EGF's production is based on the product specifications received from FSR (the fictitious name chosen for the French retailer). Along with the products' specifications, FSR has technical and social requirements in order to ensure the continuous improvement in the performance of the factory as well as respecting the workers' welfare and rights in a good working environment.

In this research, Egypt was chosen as a context for conducting the case study for many reasons. In the last few decades, Egypt has grown dramatically in terms of foreign investments (HassabElnaby et al., 2003). The low labour cost in Egypt has attracted foreign buyers to extend their GPNs to the Egyptian market. In addition to this, the geographical proximity of Egypt to the foreign markets has supported its involvement in various GPNs. Simultaneously, the Egyptian government policies supported opening the country's boundaries to the access of foreign buyers to interact with the Egyptian manufacturers. So, these factors combined have made Egypt a suitable context for understanding the influence of the global forces (represented in the GPN requirements) on the management control practices of the supplier side of the network.

In order to study the management control practices in this factory, I am using the work of Hardt and Negri (2000), Empire, which provides an analysis of the contemporary phase of global capitalism, the transformation from an industrial to an informational economy, and the influence on the geographical distribution of the production process and the constitution of production networks. In different parts of Hardt and Negri (2000) work, their discussion has resonated with both my perception of the dynamics of the contemporary world and the initial observations I had about the case factory and its relationship with the French customer. Empire presents a new lens for understanding GPN. Also, using Empire to study an Egyptian context represent a theoretical contribution where the assumptions of Empire that have been developed in western context will be taken a further step to study a different context. The Egyptian context may show some exceptions from what Hardt and Negri have assumed.

\section{Research Question}

The research is about studying the role of management control practices in global production networks (GPNs). In EGF, the relationship with FSR is founded on the transfer of knowledge from FSR as manifested in their requirements in terms of the product specification, quality and time of delivery. However, these are not the only requirements. In order for the factory to be selected as a supplier to foreign retailers, the factory goes through 
a detailed process of auditing in which the customer practices their negotiating power by asking for specific changes in the factory in terms of its structuring practices, human rights practices, and quality control procedures, as well as management control practices. The management control requirements include cost reduction strategies, performance measurements, and reward systems for workers. The factory's management collaborates with the customer's team to apply these changes. The customer is depending on visual information tags hung all over the factory and electronic reports as well as the physical attendance and observation of their team members as communication mediators through which they diffuse the required knowledge to the factory and also view the factory's operations. Techniques such as expanding the workers' skills, self and peer controls, and group rewards are gradually taking place on the shop floor in order to meet the requirements of the customer.

So, this research aims at answering the question: How can GPN requirements influence the mundane management control practices in the supplier's factory? And how can a post-Foucauldian framework explain the role of management controls in GPNs?

The work of Hardt and Negri will be narrowed down to reflect one of the main arguments in the work of Hardt and Negri about the "production of the social reality along with the subjectivities that animate it" (Hardt and Negri, 2000,p. 22). Hardt and Negri (2000, p.24) argue that, in the contemporary form of global sovereignty (i.e. Empire), the relationship between power and individuals (subjects) is moving from a "static relationship", found in disciplinary societies, to a dynamic one in which power "becomes an integral, vital function that every individual embraces and reactivates of his or her own accord", which is found in societies of control. Their work about the passage of social forms from a disciplinary society to the society of control was recognized by Foucault and continued by the work of Gilles Deleuze. In 1998, Michael Hardt situated the work of Deleuze regarding the passage towards a society of control (the concept will be explained in details in a later section) as central to understanding Empire (Hardt, 1998). He argued that "the social form of this new Empire that we are living today is the global society of control" (Hardt, 1998, p.140). Hardt and Negri argued that the concept of the society of control "describes central aspects of the concept of Empire" (Hardt and Negri, 2000, p.25). So, in that sense, the passage toward a society of control is connected to the passage towards a post-industrial form of economy in which institutions become more flexible and fluid (Simon, 2005).

In the current post-industrial form of economy, the structure of institutions that Hardt and Negri (2000) described as production networks replaced the assembly line that used to be confined within the territories of the factory. In that context, GPNs are used as one of the post-industrial economic mechanisms that are facilitating the production and reproduction of the contemporary 'imperial' form of society i.e. "the global society of control" (Hardt, 1998, p.140). The transformation from factory-based modes of production to network-based modes of production will affect the modes of governance used in these networks. Hardt and Negri (2000, p.297) argue that "the decentralization and global dispersal of productive processes and sites, which is characteristic of the post-modernization or informatisation of the economy, provokes a corresponding centralization of the control over production". The research is concerned with understanding how the controls in the production networks work, 
i.e., how the network leader (Gereffi, 1994) exerts control over its suppliers. In the light of the argument about the transformation from disciplinary societies to societies of control, the research investigates whether the controls in GPNs are reflecting this transformation or not.

\section{Case Study}

Interestingly, in qualitative research there is no right or wrong research design, however, there is a relevant or irrelevant design (Silverman and Marvasti, 2008). The decision about the relevancy/irrelevancy of a specific research design is guided by the ontological and epistemological position of the research as well as the nature of the research question (Morgan and Smircich, 1980).

A case study is defined as "an empirical inquiry that investigates a contemporary phenomenon in depth and within its real-life context, especially when the boundaries between phenomenon and context are not clearly evident" (Yin, 2009, p.18). However, the definition of case study provided by Yin was criticised as being a positivist definition of the nature of case study. Yin's definition implies that the object of enquiry is the phenomenon itself. However, Berry and Otley (2004) cited Stake's definition of a case study from a relativist point of view. According to Stake, "we study a case when it is of very special interest. We look for the detail of interaction within its contexts. A case study is the study of the particularity and complexity of a single case, coming to understand its activity within important circumstances" (Berry and Otley, 2004, pp. 234-235). Stake's definition of the case study is more relevant to the nature of the research conducted in this research. The interest and choice of the case factory were not a consequence of the interest in studying a phenomenon that can be found in different sites. However, the case itself was the spark that initiated this research. I believe that the topic of this research would be completely different if I gained access to another site.

One of the main factors in my guidance towards the choice of the case study as the research design is the nature of the research question. Yin (2009) argued that a case study is suitable for research that starts with 'how' and 'why'. The research question raised in this research is a 'how' question that is aiming to understand the relationship between the case factory and its management with the customer company within the broader GPN. Within this relationship the day-to-day management control practices in the factory is investigated in order to understand how the GPN requirements are reflected in these practices (if this is the case). In that regard, the case study enabled me to gain detailed information about the management control practices within the case factory.

In accounting research, specifically in management accounting, a case study has proved popular among the other methods used (Scapens, 2004; Parker, 2012). This popularity is attributed to the case study's "richness in addressing the task of understanding and theorising the content, processes and context of the practice of accounting" (Berry and Otley, 2004, p.231). However, a case study has been criticised in different aspects. These critiques were defended by some researchers (Flyvbjerg, 2006; Yin, 2009). Critics of the use of case studies can be categorised into two groups. The first group is concerned with the nature of the case study, the type of information collected from it and the driven conclusions, as compared to positive and quantitative methods of research. From this perspective, the 
case study is criticised for its lack of following orderly procedures, providing little basis for generalisation, and its consumption of time (Berry and Otley, 2004; Yin, 2009).

The second group of criticisms is derived from an interpretive point of view. Adams et al., (2006) articulated these criticisms in three main points.

"Firstly, case studies are conducted primarily in a single or few organisations embedded in a larger population. Thus, it is difficult to draw boundaries for the area of study with respect to exploring larger systems. Secondly, the interpretation of the social reality raises the problem of his/her bias, as the researcher in this context cannot be regarded as an independent observer. Finally, assurances of confidentiality for gaining access to the organisation raise problems in writing case reports." (Adams et al., 2006, p.365)

The above criticisms of case studies cannot be simply refuted. However, I believe that the degree of the threat of these criticisms can vary from one case to another. In terms of this research, the case factory is studied within its context, and not only the local context but also the global one. The aim of the research is to investigate the management control practices in the factory in the light of the requirements of the GPNs in which this factory is located. Therefore, drawing boundaries between the case and the larger context in which it is embedded was a long way from the focus of this research. Additionally, one of the main motives for accounting researchers' use of the case study as a research method is its ability to provide researchers with the tools required for studying "operation of accounting, both content and processes, in its organisational, social and societal contexts" (Berry and Otley, 2004, p.250). The objectivity of the researcher in conducting the case study is not claimed in this research. During the case study, my role as a researcher can be understood in the category of a visitor, as explained by Scapens (2004). In that form "the act of asking a question about these issues can have an impact upon those who are the subject of the research" (Scapens, 2004, p.264).

Personally, I did not find the final criticism (the effect of confidentiality assurance on the writing of case report) to be a significant one, at least in this research. I would like to confirm that I gave an assurance regarding the confidentiality of the name of the factory as well as the anonymity of the participants (see Appendix 1 for a sample of the consent form). The consent form was translated in Arabic (the mother tongue of the interviewees) in order to guarantee their understanding to its content. Conducting the case study in a country different from the one in which I am taking my $\mathrm{PhD}$ qualification makes it difficult for the small group of research readers to recognise the identity of the company or the people involved. During data collection and the writing of the analysis, I was always concerned about the confidentiality of the case factory. Then I realised that in the business world many companies are similar to each other. I believe that for the reader to be able to release the anonymity of the case, and be able to exactly identify it, would be a very difficult task.

\section{Research Procedures}

In this section I will go through the practical steps I went through in conducting the case study. The journey starts with the long process of negotiating and securing access. The 
challenges of this process resulted in changing the research topic several times. The preparation and planning for the data collection stage, the experience in the field, the methods followed for collecting the data and finally the analysis of the data collected are the steps that followed to secure access.

\section{Securing Access}

Securing access for conducting the case study was a very challenging process during the first six months of my PhD which was from September 2012 until March 2013. During that period, I had to change my $\mathrm{PhD}$ topic three times because of access negotiations. I started my $\mathrm{PhD}$ with an interest in studying joint ventures as one of the post-bureaucratic organisational forms and understanding the role of management accounting and controls within these joint ventures. For that topic, I prepared a proposal and targeted different joint venture companies or parent companies that have joint ventures with another company. I targeted both the UK and Egyptian markets to secure access. However, after four months of effort, getting access seemed difficult. During that time, I became more interested in studying issues around globalisation and its influence on the local practices of management accounting and developed a passion for studying an Egyptian case. I started to have an interest in investigating one of the World Bank's projects in Egypt. After tracing different managers in some of the projects in Egypt, my efforts did not result in successful access. Then I decided to re-contact the management of the company in which I conducted the case study during my Master's Degree in Egypt. The owner and founder of this company came from a very poor family but had managed to start his company from scratch and eventually made it one of the most successful companies in the Middle East. Studying his life trajectory and the role of management accounting in supporting his decisions along this path to success was of interest to me. Unfortunately (or perhaps fortunately) the access request was rejected.

After these three trials, I decided (with the advice of my supervisors) to secure access first and then articulate the research topic based on the case circumstances. Here, it is worth mentioning that after the revolution in Egypt on 25th January 2011 and during the Muslim Brotherhood governing period, the economic and political situation in Egypt was in real crisis. These circumstances made the process of securing access through formal ways very difficult. Also, during that period, many of the companies stopped their operations or incurred losses. So the request to conduct an accounting case study was usually met with rejection. The reasons given for this were either worry by companies' management about showing financial data about their performance or they were worried about revealing their actual management accounting and control practices. Some presumed that I, as a researcher, would discover that they were not following the standard practices of managing companies that we study in undergraduate books. It was difficult to persuade them that the aim of research was not to look for and detect text-book practices but instead to understand the real practices of management accounting and controls. However, their fears were understandable because in Egypt, the kind of research that require generous access is not familiar. In these companies, accounting researchers would ask for accounting figures and these are confidential and not for research.

Informal personal relations were the only way to follow in order to secure access. Although many of their trials failed as well, one of my professors in my home university was able to 
help me in accessing the case company, which is one of the Egyptian garment factories (called EGC for anonymity). The company is a family owned business which started in the mid of 1970s. At that point I knew that the company exports all its production to American and European markets. Fortunately, the owner has an academic background and encourages Masters and $\mathrm{PhD}$ researchers to conduct their research. A letter from my supervisor, supported by the research proposal, was submitted to the company owner to support the informal access request.

\section{Field Work Planning}

Access to this company was secured in March 2013. Through phone calls and emails, I collected some initial information about the company in terms of its size, the number of workers, the scope of operations, the annual turnover, and the production capacity. Also, the founder (the chairman of the company) sent me a written document explaining his personal trajectory from being a manager in Government companies to his decision to start his private business. In that document, he indicated the different factors that influenced his management style, ranging from his experience in previous Government garment companies and travels to the United States to visit garment factories and gain a Master's Degree from one of the universities there, and ending with his trust-based relationship with one of his previous managers. All these factors, from his point of view, shaped his managerial experience.

Drawing from this information, I started shaping the research question and delineated the frame of the research topic. I was interested in studying management accounting practices in a non-Western company and understanding how management accounting and control systems are conceptualized in a non-Western context, and also how this conceptualization is reproduced in the practices of management accounting and controls. I started reading management accounting and control literature in non-Western and developing countries as well as starting the journey of searching for a relevant theoretical framework that could provide an explanation of the case findings. The next step in the plan was to visit the company for a pilot study during my annual holiday (which lasted for one month) from August to September 2013.

That summer, August 2013, was not an ordinary summer in Egypt. On 30th of June 2013, the second Egyptian revolution against the Muslim Brotherhood was sparked resulting in the deposition of the President on the 3rd of July. The situation did not end peacefully. Gunned Muslim Brotherhood members started protesting and occupying Rabaa Square and promoted violent actions from the side of the Muslim Brotherhood all over the country. On 14th of August, this occupation was brought to an end by the Police and Army. This adjournment resulted in the enactment of a curfew in most of the governorates. This curfew, as well as the many violent actions which took place, made the movement between the governorates and travelling on the highway very risky. The fact that my home town is three driving hours' distant from the company made the opportunity for visiting it during that time impossible. So, the plan of making the pilot study during my annual holiday was shortened to a one day visit to the company just two days before coming back to Glasgow.

Although the visit to the company was very short, I made some observations that changed 
the research question and the overall path of the research. The first observation was that the company is not exporting its own products. However, it is a supplier for a number of retailers or brand names in America and Europe. This system is called an 'order system'. In this system, the first task of the company's owner is to find customer companies. This process was done through a variety of ways: attending international exhibitions, visiting companies in their home countries with the support of the Egyptian commercial attache in that country, or through the relationships with these companies' representative offices in Egypt. Once an initial agreement with a customer company was finalized, then that company will send an audit team to review some aspects in the Egyptian company before processing an order with them. If the audit process is successful, the customer company will send the production order. This order includes detailed product specifications, the quantity required, the level of quality accepted and the delivery date.

This transition in my understanding of the position of the Egyptian company's relationship with the companies in America and Europe resulted in a change in the research question. The Egyptian company's conceptualization of management accounting and control systems is no longer shaped by local cultural, economic and political forces. Instead, it is heavily influenced by the global forces that are shaping the day-to-day operations in the company and on its shop floor. It is no longer how their practices, management accounting and control systems, the driving forces since the company's conceptualization, are guiding the company toward accessing the global market. Instead, it has become how the company strives for validation from global companies and sustains the relationship, which is shaping their response to the requirements (that influence their management control practices) of these companies.

A second observation was the nature of the requirements from the customer companies. The requirements were falling into two categories: the quality of the lives of the workers inside the factory (i.e. human rights) and the quality of the final products. From an interview with the financial manager, I found that customer requirements do not have any influence on the way he works. He may be guided by the chairman to find ways to reduce the cost of production through the reduction of overhead costs, but they still keep using traditional costing methods to calculate the production cost. Also, the process of product costing is not done within the finance department but by the chairman and the customer service members. This observation drew my attention to a change in the relationship between the Egyptian company and its customers, who are dominating. The customer is not looking at the accounting practices and not trying to standardize the accounting practices in the Egyptian company to make them similar to those applied in their companies to facilitate the visualization of operations in the Egyptian company. Instead, the collaborating companies have independent ownership of their premises. This independence is translated into a disinterest in standardizing the Egyptian company's accounting system to be compatible with the customer company's accounting system. However, the customer company's interest in the quality of the accounting systems in the Egyptian company is reflected in the price of the product supplied. Interestingly, this price was to a great extent (not absolutely because there was still a space for the Egyptian company to refuse the order from any customer company) less negotiable.

These two observations guided a change in the research questions to reflect how global 
forces (manifested in the imposed management control imperatives from the customer companies) are steering the Egyptian company towards the contemporary global order, and also how the Egyptian company's management responds to these imperatives in their day-to-day practices. The search for a relevant theoretical framework was directed towards the pool of globalization theories that can provide an explanation to this case. At this stage I made the choice of using the work of Hardt and Negri, (2000), Empire, after thorough discussions with my supervisors and also academics from other universities.

The next step was to prepare for the data collection that took place during the period from November 2014 to February 2015. Three months is the maximum allowable period from my sponsor for data collection. The theoretical background guided the planning stage to the main study.

\section{In the Field: Challenges and Data Collection Methods}

During the period between securing access and visiting the company in August 2013, I maintained contact with the owner of the company through emails and sometimes phone calls. As a sponsored $\mathrm{PhD}$ student, I had to get approval from my sponsor before leaving the UK and heading to Egypt for the data collection process. I got the approval in October 2014. When I tried to reach the owner of the company to inform him about the starting date of data collection, I did not get a reply either through phone or email. However, I had no choice except to go back and start the data collection, especially as I had started my third year of $\mathrm{PhD}$ and had still not gone for data collection. In my first call to him after a few days of my arrival, I received the biggest shock, the worst scenario that I did not expect, when he told me that they had sold the factory due to financial problems. This call threatened all the stages I had passed through during the previous two years. However, by the end of the call and upon asking for a solution to this situation (especially that I had a limited period for achieving the data collection) the owner told me that he was in contact with the new buyer and one of his sons was still working in the company. He said he could find a way to get an approval from the current owner for me to conduct my research. However, he was also reluctant in case the new owner had doubts about my identity (in case I was a spy from the old management).

He asked me to send him the proposal for the case study and the data collection plan as well as a new letter from my supervisor referring to the previous access agreement we had with him. I prepared all the documents and met him. He sent all these documents to the new owner and explained the whole situation to him. Fortunately, the new owner accepted and offered to re-secure access to the factory. However, this process took almost one month out of the three months I had for the data collection. During that time, I contacted another factory owner (through personal contacts) who was, surprisingly, liquidating his company as well. This time it was not due to financial problems but for family reasons. The grandchildren had inherited that factory, but now everyone had their own career interests and no-one was willing to run the business anymore. Fortunately, out of this situation, I managed to interview the former owner of the company for about 3 hours and the other company's owner for another 3 hours as well. Both helped to pave the way to my understanding of the field I was going to study and they were informative on several different levels of discussion: politically, economically, socially and globally. 
Although the new owner of the EGC had kept the same name as previously along with the operations and employees, a structural change had occurred. The new owner of EGC is already an owner of a group of garment factories unified under the management of GARMENCO (a fictitious name for the new headquarters for the group of factories owned by the new owner). The main consequence of the sale is represented in the consideration of the research site as a factory (called EGF for anonymity) within the GARMENCO group rather than as a standalone company. The knitting, dyeing and printing stages no longer belong to the operations of EGF. Operations in EGF start (as with all other factories of GARMENCO) with cutting, and end with packaging. In addition, some of the administrative activities were shifted to the central management and administrative office of GARMENCO. However, EGF kept its system of opening and closing hours (8:30am to 5:30pm instead of 9:00 am to 6:00 pm as in other GARMENCO factories) as well as weekends (Fridays in EGF rather than Sundays in all other GARMENCO factories). Also, most of the managers, employees and workers stayed to work at EGF under the management of GARMENCO.

Both EGC and GARMENCO are exporting companies. Their activities are mainly dependent on the exportation of products produced. They export to brands such as Benetton, Nautica, Calvin Klein, Otto, Bon Prix, Auchon, Tesco and a lot more. While EGC was exporting to different customers and may have orders from different customers at given time, the GARMENCO strategy after purchasing EGF was to devote it to the service of only one customer. This customer is a French retailer for sports garments that has a worldwide network of production (named FSR for anonymity). FSR has a local production office (called LPO for anonymity). This LPO is responsible for allocating the production orders of FSR to the validated suppliers in Egypt; conducting the audit process for validating the factories as approved suppliers for FSR; following up the production process and assisting EGF's management for improving the production processes and the state of the workers; and controlling the quality of the final products before sending them to FSR.

In the company, my objective was to trace different kinds of controls applied to the different levels of management and to understand how they are linked to FSR requirements, local government requirements or the internal strategy of the company. This objective was inspired by the reading of Hardt and Negri's idea of the production networks and the spread of the pyramidal constitution of Empire. Data was collected via semi-structured interviews, observations, documents and photos. The variety of sources for collecting evidence is one of the major strengths of the case study as a research design (Yin, 2009).

\section{Semi-Structured Interviews}

In case studies, interviews are considered a main source of information (Yin, 2009). Semi-structured interviews rely on planned themes of questions as well as emerging questions during the interview to follow up on interesting points raised by interviewees.

Creating a rapport with employees in the factory was a cornerstone in achieving the target of the data collection. In the factory, I was dealing with two types of interviewees, the managers and department staff, and the workers on the shop floor. Being introduced to these two groups was quite different. While the employees at the managerial level could 
understand my identity as a researcher and could collaborate freely (although there were some exceptions), the collaboration of workers was subject to building trust and an informal relationship with them. The rapport with the workers was built gradually. First, I decided to have tours of the shop floor with the managers of the production lines. Some workers assumed that I was a new employee in the factory and started asking their managers about who I was. Then I was introduced to them through people they felt able to trust. The second way was through joining a group of workers on the bus that takes them to the factory. I choose the bus with the same travel route. On the way to the factory, informal conversations took place with the workers that helped build trust. This group of girls was an access point for me in their production hall. In time, I become a familiar face to the workers and they were ready to answer my questions.

I conducted 35 face-to-face interviews. Most of the interviews were tape-recorded. Those that were not recorded were either because of the choice of the interviewee not to be recorded, or it was my choice so that I would not lose the spontaneity of the interviewees and their passion for contributing to the study. All interviews were in Arabic. Most of them were transcribed. However, the translation was selective for the purposes of the quotes involved in the analysis. The interviews lasted between 25 and 180 minutes.

Drawing on the research objectives, I aimed to cover almost all the factory's departments in order to get a full picture of the flow of the activities starting from the receipt of the production order until the delivery of the final products. In that regard, the interviews included the managing director, administrative manager, customer service, lab department, warehouse, sampling, cutting, marker, quality control, production planning, engineering management, production department, human resources, finance, exports department, imports department and IT department. In production halls, both managers and workers were interviewed. Also, I managed to have an interview with a member of LPO. This is in addition to the interview with the previous owner of the factory and the owner of the other factory I approached for alternative access (as mentioned in the previous section). I considered these two interviews as interviews with industry experts as they provided me with the overall picture of the export system in the garment industry in Egypt.

The interview questions concentrated on understanding the day-to-day practices conducted by each department, their contribution in satisfying the requirements of the customer company, how these activities are linked to management control practices and to what extent these activities are informed by the production network requirements. Each interviewee was able to provide me with the details that are related to their department. The managing director and administrative manager provided me with an overall picture about how the factory is operating within the broader network of production. They identified the different sources of power over the activities within the factory.

\section{Observations}

Observations provided an additional source of information to support the evidence collected from the interviews (Yin, 2009). In addition to the interviews conducted, I managed to have long hours for observations. During the data collection period I spent in the factory, I was given a seat in the marker department's office in the factory. Staying in this office with 
employees meant I was involved in the observation process all the time I was there, even on days when no interviews were scheduled. The office also has a glass wall that allows a view of the cutting department. The marker department is in direct contact with the cutting department, the cutting follow up, sample department and lab department. The time I spent in this office enabled me to make close observations of these interactions between the departments. The marker manager was also a continuous source of information for me whenever I needed a clarification of any point. I also joined the lunch break with workers on the shop floor and with the marker manager and the marker employees. During these times, they were discussing work related topics which enabled me to gain understanding about the general attitude toward the factory's management style.

Additionally, the factory has three production halls separated on two different floors. I spent more than 20 hours with the workers either observing the production halls during the working hours or in the bus with some of the workers on their journey to and from the factory. These observations were essential in giving me a real sense of the daily activities and the controls associated with them. They also gave me the chance to understand the workers', supervisors' and managers' relationships within and outside the shop floor and to understand the workers' responses to the different types of control imposed on them during the working day.

In addition to these observations, I managed to observe 10 hours of meetings between the managing director and the managers of the factory's departments. One of these meetings was with the representatives of LPO during one of their weekly visits to the factory to make a quality control examination on the finished products before their shipping to France. Attending these meetings enabled me to gain insights about the managing director's instructions to department managers, his philosophy for managing the site and solving problems, and how the relationship with the LPO is maintained. These observations gave me the opportunity to understand the actual feelings and attitudes of participants which provided a clearer picture and deeper understanding of the case researched (Robson, 1993).

\section{Documents and photos}

Documents are the third method in the methodological triangulation used in for data collection for this research. Documents played an essential role in understanding the relation between EGF and FSR. As it was difficult to gain access to FSR, documents about the requirements of FSR from its suppliers were crucial. These documents enabled me to clearly understand the requirements from FSR, the motives behind these requirements and the connection between these requirements and international bodies. Some of these documents were directly obtained from the case factory, but the majority were available online. FSR annual sustainability reports, the production rules, the supplier quality book and supplier social book are examples of these documents.

Internal documents such as the production lines' productivity reports and the production lines' plans are among the documents obtained. Workers' productivity sheets, general frame of the budgets (some information was excluded), the machines' tags that indicate the stage name and the output required, and the worker sheet for recording the hourly productivity were also collected. In addition to these documents, I managed to take some photos of the 
shop floor to highlight some of the ways of communicating the controls through the tags hung on the walls of the production halls.

\section{Data Analysis}

I partially started the data analysis during the data collection phase. However, the limited time available for data collection did not allow me to make a complete reflection on the theoretical framework during this process. Instead, this phase of analysis was simple and practical. It was in the form of notes and reflections on the interviews and observations I made. Some days I would go to the factory and spend the whole day writing these reflections on how I found the information collected to be linked to the work of Empire. Although on these days I would not schedule interviews, I preferred writing these reflections within the factory. Observing the working day during writing these reflections enhanced my understanding of what was mentioned in the interviews. Also, it gave me the chance to have informal conversations to investigate some points in more details. The fact that the factory was sold just three months before starting my data collection meant the employees were in a transformation stage. In this stage, they are always making comparisons between the current management style and the previous one indicating the advantages and disadvantages about them.

Listening to these conversations between the employees and asking questions about the previous management style had a major influence in directing the analysis toward its current focus. Although it was difficult to make a comparative study between the change in the management style and consequently the management controls, I utilized this change logic in the development of the theoretical framework. I am not comparing a current state with a previous one. Instead I am comparing a current situation with a specific theoretical argument. It was difficult to make a comparative study for many reasons. The first reason is that before the sale, EGF was a stand-alone company that was contracted with various customers. However, the situation changed after the sale. EGF became a factory following the management of GARMENCO. Therefore, the scope of organizational activities covered in the site changed, so getting a complete picture for comparison would necessitate going beyond the factory and extending the research to GARMENCO in order to see the whole picture. The time limit for data collection was a constraint on this. The second reason was the difficulty in getting reliable information about the previous style of management from the interviewees. Although most of the current interviewees were working during the previous ownership, I noticed from their conversations that there was a strong polarization and division among the interviewees in their opinions about the previous management. Some of the interviewees were strongly supporting the old management while others were totally against it. When I noticed this, I decided to use the information about the previous management as an implicit guidance for the analysis rather than to conduct a comparative study. So, it can be said that most of the inspiration behind the research's current focus happened during the data collection phase. However, it was still not clearly directed toward this argument.

After finishing the data collection, I started the second phase of the analysis process. I started reading the transcriptions of the recordings and was going through the notes and reflections done during the data collection. The analysis was done manually without any 
computer assisted software. This was mainly because the transcripts were in Arabic and I did not plan to get all of them translated. However, I did translate the quotes used in the analysis. In the initial analysis I wanted to highlight two aspects. The first aspect is the constitution of the GPN in terms of the actors involved and where their influence on the requirements from EGF can be found. In this stage, secondary resources of data were collected in order to gain a detailed account of the production network in which EGF is involved. The second aspect of the analysis was the operations inside the factory. For this part, I initially classified the information in terms of the flow of the administrative and production processes inside the factory. I started with finding the customer, then the validation and audit process, receiving the order from the customer, the sampling process, confirming the order, purchasing the raw materials and accessories, receiving the fabric, checking the fabric quality and specification, planning for production, planning the production lines, the marker, cutting, first inspection, sewing, quality control, ironing and packaging, warehousing, and the final quality control point. Parallel to these operations, I had a detailed account of the role of the human resources department, finance department, and information technology department in supporting the production activities of the factory.

This initial categorization of the data enabled me to have a clear picture about the relationship between the factory and its customer and the whole production network as well as the operations inside the factory. This phase of analysis was done in conjunction with theoretical readings in order to specify the theme of the analysis. This stage of analysis was not an easy task and it took a long time to get settled on the focus of the research. I found the work of Empire is broad and in each part of its argument I would find some relevant evidence from the case study that could reflect it. So at this stage it was an iterative process of analysing and building the theoretical framework. This process ended up with the current theoretical framework which informed the analysis of the case study.

The discussion flows from the apparel global production networks and its dynamics to the role of the Egyptian government and the global trade agreements in connecting the textile industry in Egypt with the global actors of the network. Then the discussion goes more specific to the efforts of the Egyptian manufacturers to get into inter-organizational relationships with the brand names and big retailers, as the case with EGF. The discussion will end with a specific discussion about EGF and its relation with FSR. In order to provide a detailed discussion of the influence of FSR's requirements on EGF's management controls, I choose Merchant (1998) model for controls.

\section{Conclusion}

This reflection is an exciting experience for me. My previous background of research was completely different. It was fortified with a functional approach seeking how solutions can be offered by doing a research project. The engagement of this case study readdressed my thinking about research. Firstly, I have realised that research is not about seeking practical solutions to identified management problems. Instead, we need to identify a research question in a chosen stream of literature by critically evaluating that body of knowledge and engage in an intellectual effort to address that question. By addressing the question, we mean an exertion of a challenge the underlying assumptions of the body of knowledge in 
question. Secondly, in a case study, we merely should not "describe" what has happened by romanticising the methods adopted in a management change programme or organizational transformation project. Instead, we should use a theory to challenge the dominant views of management control (e.g. contingency theory which discusses the cross-sectional relations) while illustrating a "mystery" in the case study. The mystery I created in my work is the how GPNs rather than internal management policies orchestrate the ways in which management control systems are designed and maintained. Finally, in a case study, we should not expect a form of "statistical generalisation" to validate the findings externally in relation to wider population. This is a misunderstanding about the meaning of case studies. Instead, we should engage in a debate towards a "theoretical generalisation" where one can argue whether the theoretical perspective used is completely applicable to justify the story or whether there are some challenges to that perspectives in certain respects. In my work, although "Empire" works in some respects, there is still a question whether there is a complete transformation of disciplinary controls into a state of society of control. This leads us to call for further case studies.

\section{References}

Adams, C., Hoque, Z. \& Mcnicholas, P. (2006) Case studies and action research. Z. Hoque (Ed.), Methodological issues in accounting research: theories and methods, Spiramus Press, London, pp. 361-373.

Ansari, S. L. \& Bell, J. (1991) Symbolism, Collectivism and Rationality in Organizational Control. Accounting, Auditing \& Accountability Journal, 4, 4-27.

Anthony, R. N. (1965) Planning and Control Systems: A Framework for Analysis, Boston. Graduate School of Business Administration Harvard University.

Barrett, M., Cooper, D. J. \& Jamal, K. (2005) Globalization and the Coordinating of Work in Multinational Audits. Accounting, Organizations and Society. 30, p. 1-24.

Baxter, J. \& Chua, W. F. (2003) Alternative Management Accounting Research-Whence and Whither. Accounting, Organizations and Society. 28, p.97-126.

Berry, A. J. \& Otley, D. T. (2004) Case-Based Research in Accounting. The real life guide to accounting research, pp. 231-55.

Berry, A. J., Capps, T., Cooper, D., Ferguson, P., Hopper, T. \& Lowe, E. A. (1985) Management Control in an Area of the Ncb: Rationales of Accounting Practices in a Public Enterprise. Accounting, Organizations and Society. 10 p. 3-28.

Bhimani, A. \& Bromwich, M. (2009) Management Accounting in a Digital and Global Economy: The Interface of Strategy, Technology, and Cost Information. In: Chapman, C. S., Cooper, D. \& Miller, P. (eds.) Accounting, Organizations and Institutions: Essays in Honour of Anthony Hopwood. New York, United States, Oxford University Press Inc. 
Boedker, C. \& Chua, W. F. (2013) Accounting as an Affective Technology: A Study of Circulation, Agency and Entrancement. Accounting, Organizations and Society. 38, p. 245-267.

Burchell, S., Clubb, C., Hopwood, A., Hughes, J. \& Nahapiet, J. (1980) The Roles of Accounting in Organizations and Society. Accounting, Organizations and Society.5, p. $5-27$.

Busco, C., Giovannoni, E. \& Scapens, R. W. (2008) Managing the Tensions in Integrating Global Organisations: The Role of Performance Management Systems. Management Accounting Research. 19, p. 103-125.

Cooper, D. (1983) Tidiness, Muddle and Things: Commonalities and Divergencies in Two Approaches to Management Accounting Research. Accounting, Organizations and Society.8, p. 269-286.

Cooper, D. J. \& Hopper, T. (2006) Critical Theorising in Management Accounting Research. Handbooks of management accounting research. 1, p. 207-245.

Cruz, I., Scapens, R. W. \& Major, M. (2011) The Localisation of a Global Management Control System. Accounting, Organizations and Society. 36, p. 412-427.

Dekker, H. C. (2004) Control of Inter-Organizational Relationships: Evidence on Appropriation Concerns and Coordination Requirements. Accounting, Organizations and Society. 29, p. 27-49.

Deleuze, G. (1992) Postscript on the Societies of Control. October. 59, p. 3-7.

Dent, J. F. (1996) Global Competition: Challenges for Management Accounting and Control. Management Accounting Research. 7, p. 247-269.

Flyvbjerg, B. (2006) Five Misunderstandings About Case-Study Research. Qualitative Inquiry. 12, p. 219-245.

Foucault, M. (1977) Discipline and Punish: The Birth of Prison. London, Penguin Books.

Gereffi, G. (1994) The Organization of Buyer-Driven Global Commodity Chains: How U.S. Retailers Shape Overseas Production Networks. In: Gereffi, G. \& Korzeniewicz, M. (eds.) Commodity Chains and Global Capitalism USA, Greenwood Publishing Group, Inc.

Geringer, J. M. \& Hebert, L. (1989) Control and Performance of International Joint Ventures. Journal of international business studies, p. 235-254.

Giddens, A. (1990) The Consequences of Modernity, Cambridge, Polity Press.

Giddens, A. (1991) Modernity and Self-Identity, Cambridge, Polity Press. 
Groot, T. L. C. M. \& Merchant, K. A. (2000) Control of International Joint Ventures. Accounting, Organizations and Society, 25, 579-607.

Hardt, M. \& Negri, A. (2000) Empire, Harvard University Press.

Hardt, M. \& Negri, A. (2000) Empire, Harvard University Press.

Hardt, M. (1998). The Global Society of Control. Discourse. 20, p. 139-152.

Hassabelnaby, H. R., Epps, R. W. \& Said, A. A. (2003) The Impact of Environmental Factors on Accounting Development: An Egyptian Longitudinal Study. Critical Perspectives on Accounting. 14, p. 273-292.

Hopwood, A. G. (1976) Editorial. Accounting, Organizations and Society. 1, p. 1-4.

Hopwood, A. G. (1983) On Trying to Study Accounting in the Contexts in Which It Operates. Accounting, Organizations and Society. 8, p. 287-305.

Horngren, C. T., Datar, S. M. \& Foster, G. (2003) Cost Accounting: A Managerial Emphasis. New Jersey, Pearson Education International.

Merchant, K. A. (1998) Modern Management Control Systems: Text and Cases. Upper Saddle River, New Jersey, Prentice-Hall, Inc.

Miller, P. \& O'leary, T. (1987) Accounting and the Construction of the Governable Person. Accounting, Organizations and Society.12, p. 235-265.

Moilanen, S. (2007) Knowledge Translation in Management Accounting and Control: A Case Study of a Multinational Firm in Transitional Economies. European Accounting Review. 16, p. 757-789.

Morgan, G. \& Smircich, L. (1980) The Case for Qualitative Research. Academy of Management Review. 5, p. 491-500.

Neu, D., Rahaman, A. S. \& Everett, J. (2014) Accounting and Sweatshops: Enabling Coordination and Control in Low-Price Apparel Production Chains. Contemporary Accounting Research. 31, p. 322-346.

Parker, L. D. (2012) Qualitative Management Accounting Research: Assessing Deliverables and Relevance. Critical Perspectives on Accounting. 23, p. 54-70.

Porter, M. E. (1985) Competitive Advantage: Creating and Sustaining Superior Performance. 1985. New York: FreePress.

Porter, M. E. (1990) The Competitive Advantage Of Nations. New York, Palgrave Publisher Ltd. 
Quattrone, P. \& Hopper, T. (2005) A 'Time-Space Odyssey': Management Control Systems in Two Multinational Organisations. Accounting, Organizations and Society. 30, p. 735-764.

Robertson, R. (1992) Globalization: Social Theory and Global Culture, Sage.

Scapens, R. W. (2004) Doing Case Study Research. The real life guide to accounting research. p. 257-279.

Silverman, D. \& Marvasti, A. (2008) Doing Qualitative Research: A Comprehensive Guide. Thousand Oaks. CA, Sage Publications.

Simon, B. (2005) The Return of Panopticism: Supervision, Subjection and the New Surveillance. Surveillance and Society. 3, p. 1-20.

Tinker, A. M. (1980). Towards a Political Economy of Accounting: An Empirical Illustration of the Cambridge Controversies. Accounting, Organizations and Society. 5, p. 147-160.

Tsamenyi, M., Noormansyah, I. \& Uddin, S. (2008). Management Controls in Family-Owned Businesses (Fobs): A Case Study of an Indonesian Family-Owned University. Accounting Forum. 32, p. 62-74.

Wickramasinghe, D. \& Alawattage, C. (2007) Management Accounting Change: Approaches and Perspectives, Abingdon, Oxon, Routledge.

Yin, R. K. (2009) Case Study Research: Design and Methods, Sage publications. 